\title{
PELATIHAN PEMBUATAN DAN PENGGUNAAN HAND SANITIZER OTOMATIS MENCEGAH COVID-19 DAN SANTUNAN ANAK YATIM DHUAFA
}

\author{
Marfin $^{1)}$, Ariyawan Sunardi ${ }^{2)}$, Aripin Triyanto ${ }^{3)}$, Seflahir Dinata ${ }^{4)}$, Edwar \\ Mualim $^{5)}$, Nanang Ardianto ${ }^{6}$, Sefudin Tahang ${ }^{7)}$, Fitra Ramdhani ${ }^{8)}$, Danu Ikhsan9) \\ 1,2,3,4,5,6,7,8,9 Program Studi Teknik Elektro, Fakultas Teknik, Universitas Pamulang
}

\begin{abstract}
Abstrak
Pandemi Virus Corona (Covid-19) telah terjadi di dunia dan melanda juga Indonesia. Korban meninggal dunia di Indonesia sudah mencapai 6021 orang per tanggal 14 Agustus 2020 (www.covid19.go.id). Penambahan positif Covid-19 sebanyak 2377 kasus, hal ini menunjukkan Covid-19 merupakan masalah serius. Obat maupun vaksin Covid-19 masih dalam tahap penelitian dan uji coba. Pencegahan dan pemutusan penyebaran Covid-19 merupakan upaya yang lebih baik daripada pengobatan. Penerapan protokol kesehatan merupakan upaya pemutusan Covid-19. Salah satu media penyebaran penyakit adalah tangan setelah melakukan berbagai aktivitas. Cuci tangan dengan hand sanitizer meruakan salah satu pola hidup baru dalam era new normal. Pengabdian Kepada Masyarakat (PKM) Prodi teknik Elektro Universitas Pamulang (UNPAM) yang berlokasi di Musholla Al Ikhlas Jln. H. Rean Pamulang Tangsel berupa pembuatan hand sanitizer otomatis. Hand sanitizer otomatis ini dilengkapi sensor ultrasonic untuk mendeteksi adanya suatu benda yang mendekat pada kasus ini contohnya adalah tangan. Alat ini dapat bekerja ketika user mengarahkan tangannya kearah sensor ultrasonic dan sensor ultrasonic mendeteksi adanya tangan. Mode otomatis dirancang bekerja secara otomatis untuk mengalirkan cairan hand sanitizer, dan mengarahkan cairan tersebut ke tangan pengguna. Para peserta PKM begitu antusias mengikuti pelatihan pembuatan hand sanitizer otomatis. Momen ramadhan juga dimanfaatkan untuk pemberian santunan anak yatim dan pembagian sembako kepada para dhuafa terdampak Covid-19. Pelatihan pembuatan hand sanitizer otomatis dan pembagian santunan anak yatim serta pembagian sembako untuk dhuafa merupakan rangkaian PKM yang berjalan sukses dan lancar.
\end{abstract}

Kata kunci : Covid-19, hand sanitizer otomatis, santunan yatim dhuafa, Musholla Al Ikhlas Jln. H. Rean

\begin{abstract}
The Corona Virus Pandemic (Covid-19) has occurred in the world and has also hit Indonesia. The death toll in Indonesia has reached 6021 people as of August 14, 2020 (www.covid19.go.id). The addition of positive Covid-19 cases to 2377 cases, this shows that Covid-19 is a serious problem. The Covid-19 drug and vaccine are still in the research and trial stages. Preventing and stopping the spread of Covid19 is a better effort than treatment. The implementation of the health protocol is an effort to end Covid-19. One of the media for spreading the disease is the hands after doing various activities. Washing your hands with a hand sanitizer is a new lifestyle in the new normal era. Community Service (PKM) Electrical engineering study program, Pamulang University (UNPAM) located at Musholla Al Ikhlas Jln. H. Rean Pamulang Tangsel in the form of making automatic hand sanitizers. This automatic hand sanitizer is equipped with an ultrasonic sensor to detect an object
\end{abstract}


approaching in this case, for example, a hand. This tool can work when the user points his hand towards the ultrasonic sensor and the ultrasonic sensor detects the presence of a hand. Automatic mode is designed to work automatically to drain the hand sanitizer fluid, and direct the liquid to the user's hand. The PKM participants were very enthusiastic about taking part in the training for making automatic hand sanitizers. The moment of Ramadan is also used to provide donations for orphans and distribution of basic foodstuffs to poor people affected by Covid-19. The training on making automatic hand sanitizers and the distribution of donations for orphans and the distribution of basic foodstuffs for the poor were a series of PKM that ran successfully and smoothly.

Keywords: Covid-19, automatic hand sanitizer, donation for orphans of the poor, Musholla Al Ikhlas Jln. H. Rean

Correspondence author: ariyawan sunardi, dosen00332@unpam.ac.id, South Tangerang, and Indonesia

\section{PENDAHULUAN}

Penggunaan Hand sanitizer otomatis merupakan upaya kebiasaan baru dalam new normal untuk memutus Covid-19). Dalam perencanaan pelatihan, pemasangan dan perawatan hand sanitizer otomatis, terdapat beberapa hal yang perlu diperhatikan sebagai berikut:

1). Tegangan Yang Dibutuhkan

Hand sanitizer otomatis menggunakan arduino sebagai mikrokontroler, Koneksi USB atau catu daya eksternal untuk mengaktifkan mikrokontroller Arduino Arduino akan memilih secara otomatis sumber daya yang digunakan. Adaptor AC-DC maupun baterai merupakan sumber daya eksternal (non-USB). Adaptor dihubungkan menggunakan steker 2,1 mm yang terminal positif bagian tengan ke ke jack sumber tegangan pada board. Jika menggunakan baterai, tegangan dapat langsung dihubungkan melalui header pin Gnd dan pin Vin dari konektor POWER.

Board Arduino beroperasi pada tegangan eksternal 6 - 20 Volt. Jika tegangan kurang dari 7 Volt, maka pin 5 Volt akan menghasilkan tegangan kurang dari 5 Volt. Pada kondisi ini, board menjadi tidak stabil. Sebaliknya jika sumber tegangan lebih dari 12 Volt, regulator tegangan akan mengalami panas berlebihan dan bisa merusak board. Rentang sumber tegangan yang dipilih adalah 7 - 12 Volt.

2). Program pada Arduino Ide

Program arduino pada arduino ide harus diperhatikan karena arduino uno akan bekerja sesuai program yang telah dicoding pada arduino ide. Pada alat hand sanitizer otomatis ini yang bisa diperhatikan adalah: Putaran servo sebanyak 270 derajat agar alat bisa mengeluarkan cairan antiseptic. Jarak yang dibutuhkan sensor ultrasonic dan tangan untuk mengeluarkan cairan antiseptic, pada arduino ini diprogram sebanyak $15 \mathrm{~cm}$.

3). Penempatan Alat Hand sanitizer

Alat Hand sanitizer otomatis digunakan untuk memutus penyebaran Covid19 karena dapat membunuh virus. Oleh karena itu penggunaan alat hand sanitizer 
otomatis ini sebaiknya digunakan diawal waktu sebelum melakukan kegiatan. Maka yang harus diperhatikan dalam penempatan alat hand sanitizer otomatis ini adalah:

a. Ditempatkan didepan pintu agar sebelum orang memasuki ruangan mereka menggunakan hand sanitizer terlebih dahulu.

b. Letak alat hand sanitizer otomatis sebaiknya $120 \mathrm{~cm}$ tinggi dari lantai agar mudah digunakan untuk orang dewasa dan anak-anak.

c. Penempatan alat hand sanitizer diusahakan tidak terkena percikan air agar arduino tidak terkena air sehingga bisa membuat arduino rusak.

4). Proses Isi Ulang Cairan Antiseptic

Alat hand sanitizer otomatis adalah alat yang bisa diisi ulang sehingga pada saat cairan antiseptic dalam alat hand sanitizer habis maka dapat diisi ulang, hal ini juga bisa menghemat biaya. Adapun yang harus diperhatikan dalam proses isi ulang antiseptic adalah:

a. Hendaknya berhati-hati pada saat menuang cairan antiseptic agar tidak terkena arduino pada alat hand sanitizer otomatis.

b. Sebaiknya menggunakan antiseptic atau sabun dalam proses isi ulang hand sanitizer agar dapat membunuh bakteri pada tangan.

Adapun permasalahan yang dialami masyarakat Jalan H. Rean RT 007/05, Kel. Benda Baru, Kec. Pamulang, Tangsel adalah: kekhawatiran terhadap tingginya tingkat penularan virus Covid-19 di Indonesia saat ini kususnya di wilayah pamulang Tangerang selatan. Resiko penyebaran virus Corona (Covid-19) yang bisa melalui benda mati yang tertinggal dari penderita covid-19, seperti kran air, tempat wudhu maupun benda-benda di sekitar lingkungan tempat tinggal. Meningkatnya harga hand sanitizer pada saat pandemi virus corona (covid-19) juga merupakan permasalahan yang dihadapi masyarakat.

UNPAM tergabung dalam Yayasan Sasmita Jaya mempunyai visi "Bermutu dalam pengembangan pendidikan, pengabdian masyarakat, dan pengabdian terjangkau seluruh lapisan masyarakat, berlandaskan ridha Tuhan yang Maha Esa". Sejalan dengan visi, UNPAM terus berkerjasama dengan berbagai pihak terkait dalam penerapan ilmu, teknologi dan seni sebagai wujud pelaksanaan Tri Dharma Perguruan Tinggi yakni Pendidikan, Penelitian dan Pengabdian Masyarakat. UNPAM mempunyai berbagai stakeholder yakni pemerintah pusat, pemerintah propinsi, pemerintah kabupaten/kota, dunia usaha, swasta maupun dengan masyarakat.

Masyarakat Pamulang khususnya yatim dan dhuafa Jalan H. Rean RT 007/05, Kel. Benda Baru, Kec. Pamulang, Tangsel. Lokasi kampus UNPAM tidak jauh dengan lokasi masyarakat sekitar $8 \mathrm{~km}$, maka Prodi Teknik Elektro berkewajiban ikut serta membantu berbagai persoalan yang dihadapi masyarakat. Kehadiran UNPAM seharusnya benarbenar dirasakan manfaatnya oleh masyarakat sekitar. Pemberdayaan masyarakat berprinsip melihat dari kebutuhan dan kesadaran masyarakat sendiri untuk dikelola sertadikembangkan dengan menggunakan terutama sumber daya yang ada di masyarakat tersebut. Masyarakat jalan H. Rean RT 007/05, Kel. Benda Baru adalah kelompok masyarakat yang menyatukan diri secara sukarela dalam kelompok dikarenakan adanya ikatan pemersatu, yaitu adanya visi, tujuan, kepentingan dan kebutuhan yang sama sehingga kelompok tersebut memiliki kesamaan tujuan yang ingin dicapai bersama. Sehingga kegiatan pelatihan pembuatan dan penggunaan Hand sanitizer otomatis sangat relevan dan merupakan bagian dari pada kegiatan pendampingan dengan tetap ditujukan penguatan kapasitas masyarakat sehingga bisa membangun kelompok yang terbuka, berkesinambungan, bertanggung jawab dan mandiri. 
Pelaksanaan PKM ini disusun berdasarkan hasil survey awal oleh tim PKM ke lokasi Jalan H. Rean RT 007/05, Kel. Benda Baru serta wawancara kepada masyarakat. Tujuan umum dari kegiatan PKM adalah membantu masyarakat dalam mengatasi persoalan-persoalan yang dihadapi saat ini.

Secara khusus tujuan kegiatan PKM ini adalah:

1). Membantu masyarakat untuk penerapan budaya baru dalam new normal untuk mencegah Covid-19.

2). Membantu masyarakat untuk pembuatan alat hand sanitizer otomatis.

3). Membantu masyarakat cara merawat alat hand sanitizer otomatis yang benar supaya komponenya bertahan lama dan tetap keadaan yang baik.

4). Membantu masyarakat dalam pemakaian keseharianya supaya tidak mudah rusak.

Hal utama yang ditawarkan adalah ikut memecahkan masalah yang dihadapi melalui kegiatan pelatihan pembuatan hand sanitizer otomatis kepada MasyarakatJalan H. Rean RT 007/05, Kel. Benda Baru dikemas dengan nama kegiatan "Pelatihan Hand sanitizer Otomatis Untuk Mencegah Covid-19 Dan Santunan Anak Yatim Dhuafa Yang Terdampak Covid-19 Di Bulan Ramadhan". Pelatihan ini diharapkan mampu meningkatkan keahlian dan keterampilan masyarakatJalan H. Rean RT 007/05, Kel. Benda Baru untuk menggunakan dan merawat hand sanitizer otomatis. Jadi PKM ini bisa menjadi stimulus masyarakat untuk mandiri.

Luaran dari kegiatan PKM ini akan dituangkan dalam makalah yang akan dikirim ke jurnal nasional pengabdian masyarakat. Selain itu publikasi diseminasi berita melalui media cetak maupun daring juga menjadi sasaran.

Manfaat dari kegiatan PKM diharapkan antara lain:

1). Membuka wawasan tentang penyebaran dan pencegahan virus covid-19 yang dihadapi masyarakat.

2). Menambah pengetahuan dan keterampilan dasar mengenai perbaikan dan perawatan hand sanitizer otomatis.

3). Membuka wawasan mengenai upaya pencegahan penyebaran virus corona (covid19) dengan hand sanitizer otomatis.

4). Mengetahui manajemen pemakaian listrik untuk hand sanitizer otomatis.

5). Sebagai bahan masukan bagi UNPAM, khususnya dalam mengembangkan kegiatan PKM yang berkaitan dengan jenis kegiatan Penyuluhan Masyarakat.

\section{METODE PELAKSANAAN}

Dalam pengabdian masyarakat ini pengabdi mengembangkan produk baru berupa hand sanitizer otomatis pada masyarakat Pamulang khususnya yatim dan dhuafa Jalan $\mathrm{H}$. Rean RT 007/05, Kel. Benda Baru, Kec. Pamulang, Tangsel dan menguji kelayakan pelatihan tersebut. Metode PKM yang digunakan adalah model ADDIE meliputi analisis (Analysis), perancangan (Design), pengembangan (Development), implementasi (Implementation), dan evaluasi (Evaluation).

\subsection{Analysis (Analisis)}

Analisis dilakukan pada informasi kondisi fakta yang ada di Musholla Al Ikhlas. Informasi didapatkan secara langsung dengan meninjau lokasi dan 
wawancara kepada pengurus serta jamaah Musholla Al Ikhlas. Selanjutnya dilakukan analisis kebutuhan, materi, dan kurikulum pelatihan. Analisis kebutuhan berdasarkan permasalahan hand sanitizer yang dihadapi pengurus dan jamaah Musholla Al Ikhlas. Sedangkan analisis materi berupa penentuan materi pelatihan pemasangan dan perawatan hand sanitizer yang akan disampaikan kepada masyarakat.

\subsection{Design (Perancangan)}

Tahap perancangan meliputi skema diagram hand sanitizer dan pembenahan instalasi listrik yang telah terpasang. Perancangan akan memudahkan langkah pemasangan dan perawatan hand sanitizer. Pengurus dan jamaah juga dipermudah dalam melakukan trouble shooting pasca pelatihan ini.

\subsection{Devolepment (Pengembangan)}

Instalasi hand sanitizer dan listrik yang telah terpasang sebelumnya dilakukan pengembangan untuk menjamin keamanannya. Tahap pengembangan meliputi review skema diagram hand sanitizer dan instalasi listrik yang telah terpasang. Segi keamanan instalasi listrik menjadi goal dari tahap pengembangan. Pengembangan modul pelatihan juga dilakukan pasca review dari dosen. Modul pelatihan harus mudah dipahami pengurus dan jamaah Musholla Al Ikhlas karena modul ini sebagai acuan langkah ke depan.

\subsection{Implementation (Implementasi)}

Setelah dilakukan validasi oleh dosen dan dinyatakan layak untuk digunakan, maka dilakukan penerapan modul pelatihan kepada pengurus maupun jamaah Musholla Al Ikhlas. Modul pelatihan meliputi pemasangan dan perawatan hand sanitizer berupa langkah-langkah teknis. Selain itu, penerepan wiring instalasi hand sanitizer juga dilakukan oleh pengurus dan jamaah Musholla Al Ikhlas dengan bimbingan mahasiswa maupun dosen.

\subsection{Evaluation (Evaluasi)}

Sedangkan evaluasi kegiatan dilakukan setelah kegiatan pelatihan yaitu dengan cara verifikasi pemasangan dan perawatan hand sanitizer oleh tim dosen Teknik Elektro UNPAM. Tim PKM Teknik Elektro UNPAM meminta tanggapan pengurus dan jama'ah Musholla Baiturrahman terhadap kegiatan PKM yang dilakukan. Evaluasi juga dapat dilihat ketika sesi tanya jawab maupun praktikum pemasangan dan perawatan hand sanitizer.

\subsection{Realisasi Pemecahan Masalah}

Persiapan pelaksanaan diawali dengan kick-off meeting untuk menetapkan beberapa hal mendasar, antara lain: jenis kegiatan PKM, topik PKM, lokasi, dan waktu. Pada rapat koordinasi berikutnya, ditetapkan beberapa hal seperti: susunan acara, daftar peralatan, pembuatan alat peraga, dan anggaran biaya. Sasaran 
kegiatan PKM ini adalah pengurus musholla dan jamaah musholla Al Ikhllas, di wilayah jl. Tambora Jakarta Barat. Sasaran yang diutamakan adalah pengurus musholla Al Ikhlas yang notabene menghadapi permasalahan ketidak nyamanan beribadah dengan hand sanitizer yang sudah rusak dalam penggunaan sehari-hari. Oleh karena itu untuk kelancaran kegiatan PKM, Prodi Teknik Elektro UNPAM bekerjasama dengan pengasuh pengurus dan jamaah musholla. Melalui kegiatan penyuluhan ini diharapkan wawasan dan ketrampilan pengurus musholla mengenai masalah hand sanitizernya bisa dislesaikan dengan baik.

Permasalahan bahwa Musholla Al Ikhlas belum tersedia hand sanitizer untuk menghadapi pandemi Covid-19. Sehingga kami mengadakan pelatihan pembuatan hand sanitizer otomatis untuk Musholla Al Ikhlas dalam menghadapi pandemic Covid-19.

\subsection{Khalayak Sasaran}

Tempat, sasaran dan waktu pelaksanaan kegiatan adalah sebagai berikut:

Sasaran kegiatan : Masyarakat yatim dan dhuafa Jalan H. Rean RT 007/05, Kel. Benda Baru, Kec. Pamulang, Tangerang Selatan (Musholla Al Ikhlas)

\subsection{Tempat dan Waktu}

Tempat kegiatan : Musholla Al Ikhlas

Waktu pelaksanaan : Sabtu s.d. Minggu, 09 s.d. 10 Mei 2020

\subsection{Metode Kegiatan}

Metode yang digunakan dalam PKM melalui kegiatan:

a) Penyuluhan tentang protokol kesehatan di waktu pandemic Covid-19

b) Pelatihan pembuatan desain rangkaian hand sanitizer.

c) Penyusunan modul, bahan dan perawatan hand sanitizer.

d) Santunan kepada anak yatim dan pembagian sembako kepada dhuafa terdampak Covid-19

Sedangkan evaluasi kegiatan dilakukan setelah kegiatan pelatihan kepada Pengurus dan Jama' ah Musholla Al Ikhlas yaitu dengan cara verifikasi pemasangan dan perawatan hand sanitizer oleh tim dosen Teknik Elektro UNPAM. Tanggapan masyarakat dan jama'ah Musholla Al Ikhlas juga disampaikan melalui wawancara yang dilakukan oleh Tim PKM Teknik Elektro Universitas Pamulang.

\section{HASIL DAN PEMBAHASAN}

\subsection{Tahap Persiapan}

Pada tahap ini, pelaksana melalukan survey lapangan untuk mengetahui rata - rata jamaah yang hadir di musholla Al Ikhlas dan Berapa banyak jumlah yatim dan duafa yang membutuhkan bantuan terdampak covid-19. Dari hasil tersebut kita 
dapat memperkirakan kebutuhan dari handsanitizer yang akan digunakan dan melakukan pendataan serta pengumpulan dana yang dikordinasikan dengan ketua pelaksana PKM. Pada tahap ini, pelaksana melalukan survei lapangan untuk menganalisa kebutuhan komponen yang diperlukan untuk kebutuhan pemasangan hand sanitizer. Dalam tahap ini dicari permasalahan-permasalahan masyarakat di sekitar Musholla Al Ikhlas terutama sebagai dampak covid-19. Dari hasil pendataan didapatkan data yatim piatu dan dhuafa yang terimbas pandemic Covid-19. Kami juga melihat kurangnya fasilitas hand sanitizer di rumah warga dan muholla $\mathrm{Al}$ Ikhlas. Dilanjutkan dengan persiapan peralatan dan perangkat yang dibutuhkan sebagai alat untuk pemasangan hand sanitizer nya.

\subsection{Tahap Pelaksanaan}

Pelaksanaan PKM dilaksanakan pada hari Sabtu - Minggu, 09-10 Mei 2020 pukul 09.00 - 15.00 WIB dan 13.00 - 17.00 WIB di Musholla Al Ikhlas J1. Jalan H. Rean RT 007/05, Kel. Benda Baru, Kec. Pamulang, Tangerang Selatan.

Hari Sabtu, 09 Mei 2020 dilakukan pembuatan hand sanitizer otomatis oleh tim mahasiswa : Nanang, Danu, Saefudin, Fitra, Maulana, Abdillah dan Iqbal. Hand sanitizer otomatis dibuat menggunakan mikronkontroler arduino. Acara diawali dengan pemberian sambutan-sambutan dari Ketua PKM, Ketua RT, Prodi Teknik Elektro dan Ketua DKM Musholla Al. Ikhlas Ustadz Aceng. Dilanjutkan dengan pemberian materi tentang protokol kesehatan selama Pandemi Covid-19 oleh Dosen Prodi Teknik Elektro UNPAM.

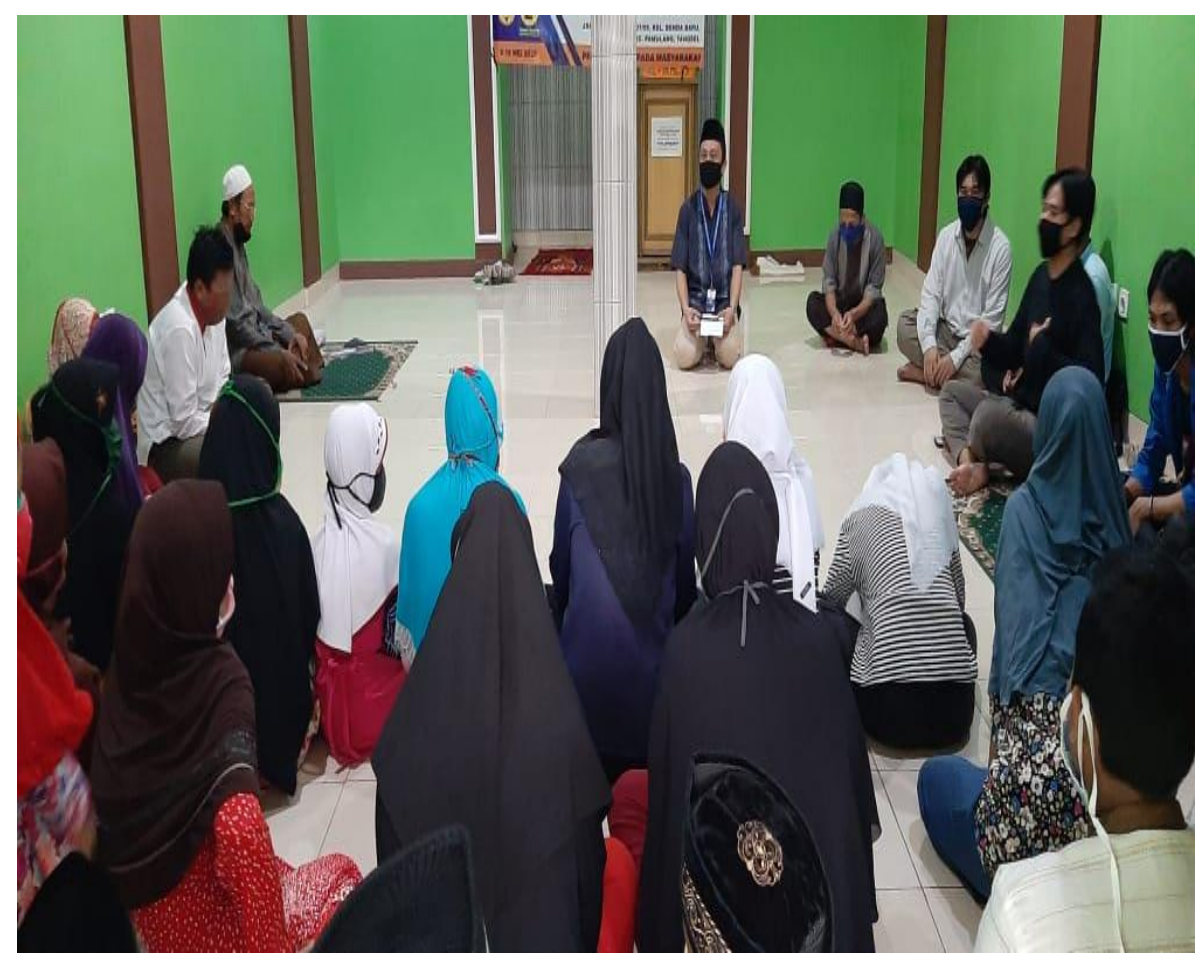

Gambar 1 Pembukaan dan Penyuluhan tentang Protokol Kesehatan 
Materi tentang pembuatan Hand sanitizer otomatis disampaikan oleh mahasiswa yaitu Nanang Ardianto, Danu Ihsan dan Saefudin.

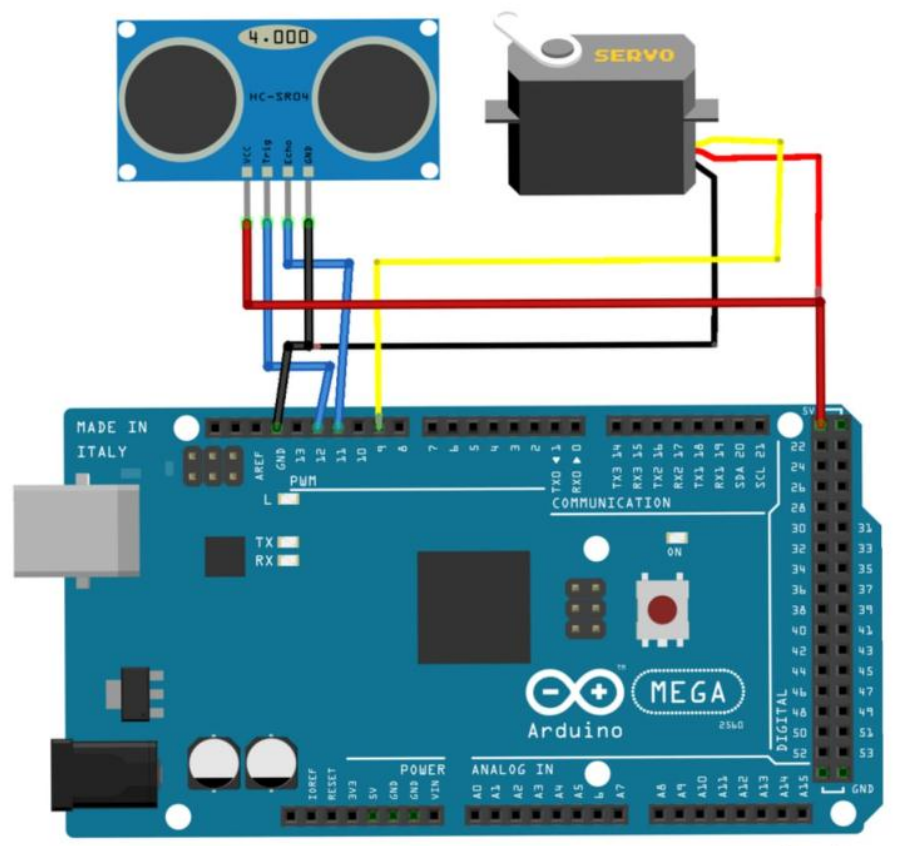

Gambar 2 Rangkaian Hand sanitizer Otomatis

Rangkaian hand sanitizer otomatis terdiri atas : mikrokontroler arduino, sensor ultrasonik dan motor servo.

Penjelasan gambar sebagai berikut :

- Pin 5V pada arduino hubungkan pada VCC motor servo dan sensor ultrasonik

- Pin Gnd (Ground) pada arduino hubungkan dengan ground motor servo dan sensor ultrasonik.

Uraian hubungan Sensor Ultrasonik yaitu :

- Vcc ke 5V

- $\quad$ Trig ke Pin 11

- Echo ke Pin 12

- Gnd ke Gnd

Sedangkan keterangan Motor Servo dijabarkan :

- Kabel Merah ke 5 V

- Kabel Kuning ke Pin 9

- Kabel Hitan ke Gnd

Rangkaian tersebut kemudian dihubungkan dengan wadah hand sanitizer. Alat akan mengeluarkan cairan hand sanitizer ketika tangan didekatkan.Seluruh warga yang hadir menyaksikan dan mencoba memakai hand sanitizer otomatis. 


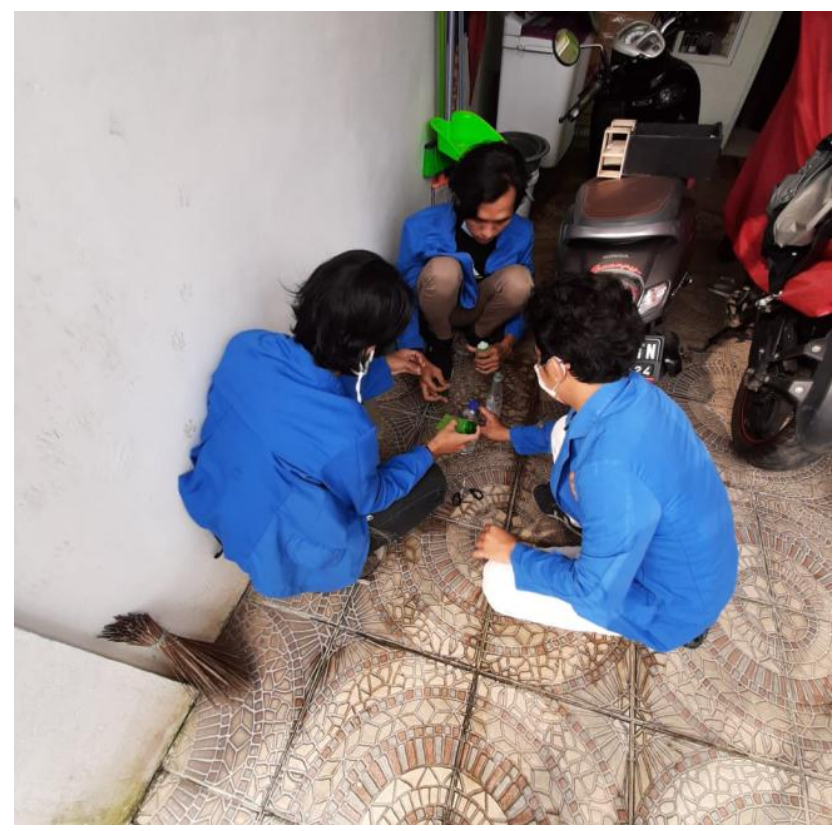

Gambar 3 Proses Pembuatan Hand sanitizer Otomatis

Setelah rangkaian penjelasan pembuatan hand sanitizer selesai, acara dilanjutkan dengan praktikum dan bimbingan mengenai pembuatan, perawatan, dan perbaikan hand sanitizer oleh para mahasiswa dan dosen pembimbing.

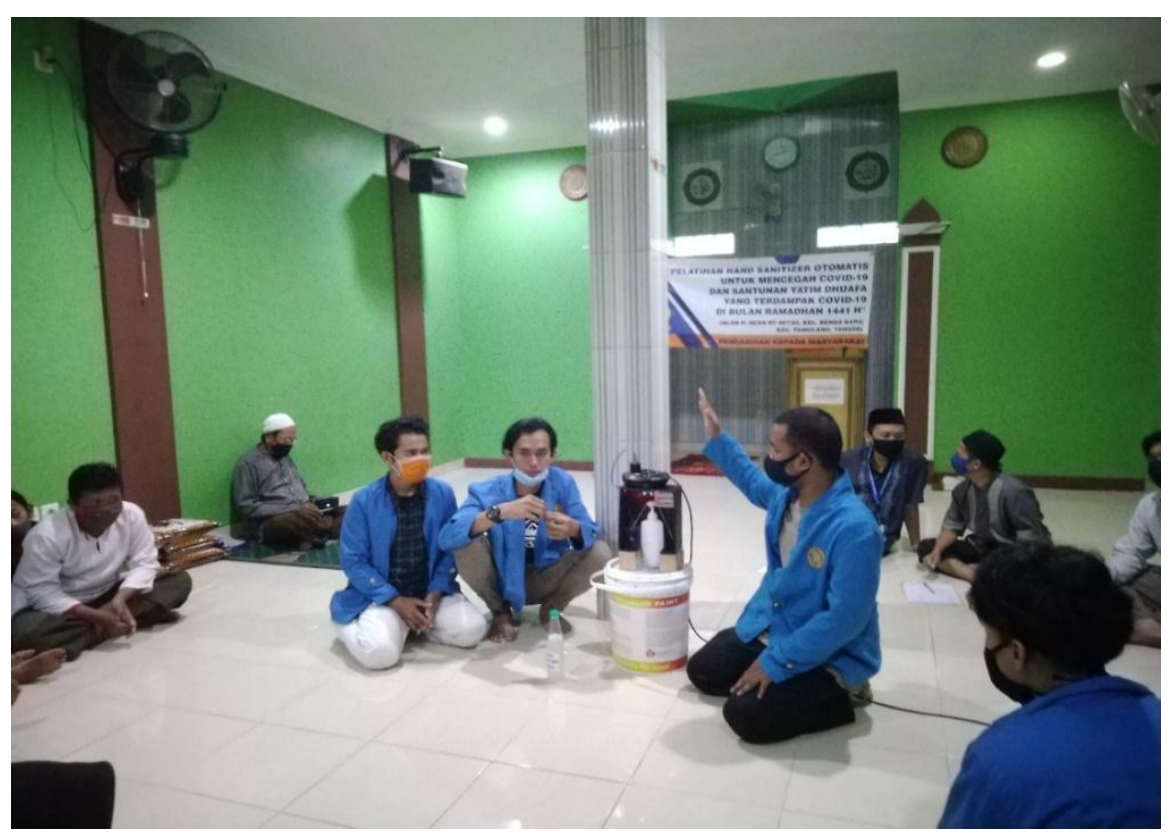

Gambar 4 Penjelasan Perawatan Hand sanitizer Otomatis

Sebagai penutup acara PKM hari Sabtu 9 Mei 2020 ditandai penyerahan simbolis hand sanitizer untuk Musholla Al Ikhlas dan doa bersama di Bulan Ramadhan. 
Lanjutan pelaksanaan PKM dilaksanakan pada hari Minggu, 10 Mei 2020 pukul 13.00 - 17.00 WIB di Musholla Al Ikhlas Jalan H. Rean RT 007/05, Kel. Benda Baru, Kec. Pamulang, Tangerang Selatan. Acara diawali dengan pemberian sambutan-sambutan dari pihak-pihak terkait, dari perwakilan dosen pembimbing sekaligus pembawa acara yaitu Ariyawan Sunardi dilanjutkan dengan Ketua RT 007 dan dilanjutkan dengan ketua DKM musholla Al Ikhlas Ustadz Aceng. Kegiatan PKM diisi dengan santunan anak yatim dan pembagian sembako untuk dhuafa yang terkena dampak pandemi Covid-19.

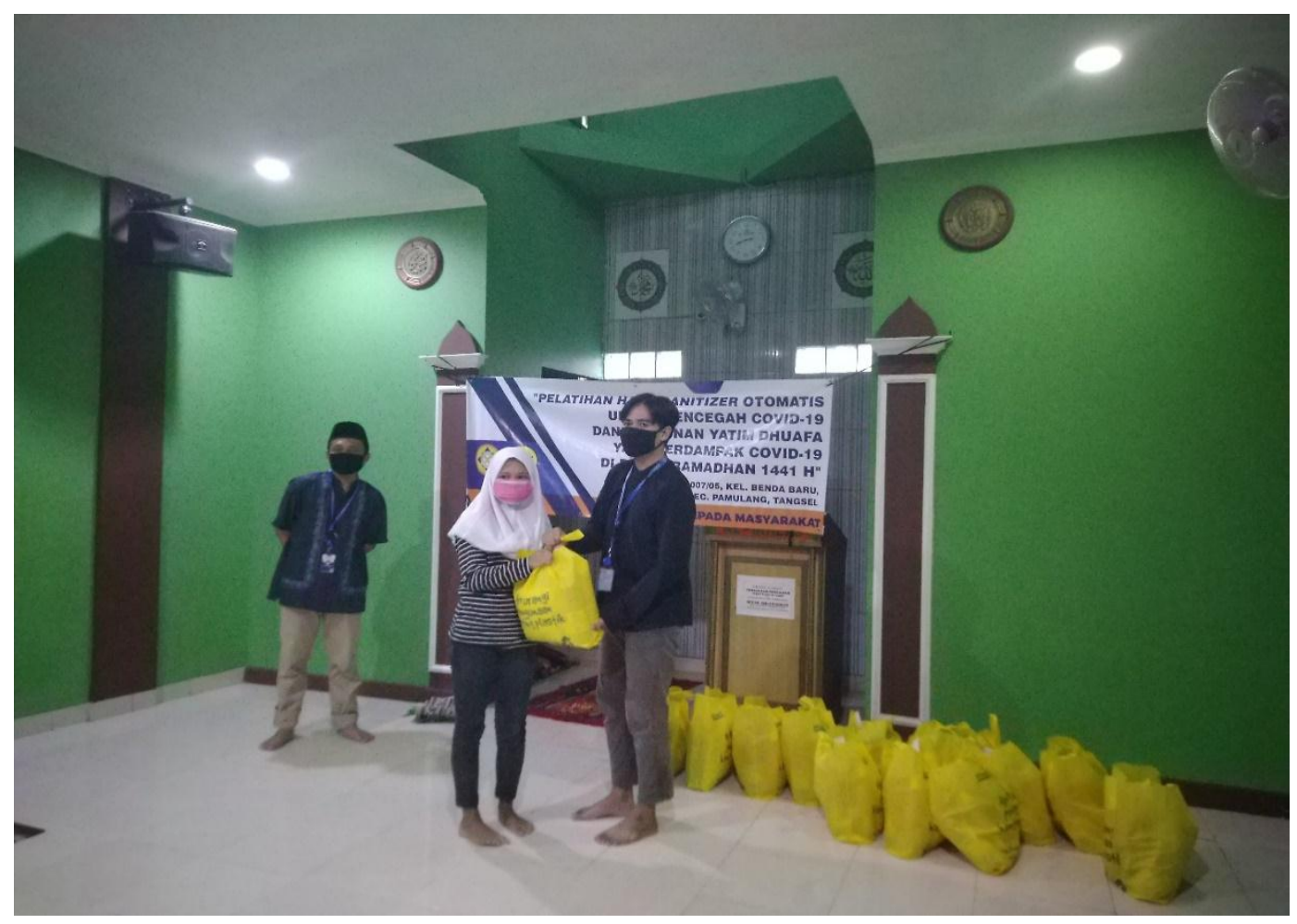

Gambar 5 Pembagian Santunan Anak Yatim dan Sembako Dhuafa

Sebagai acara penutupan kita tutup dengan doa bersama dan foto bersama para anak yatim dan dhuafa. Semoga dengan berlangsungnya progam PKM ini dapat membantu masyarakat dan sebagai wadah bersosial antara mahasiswa dan masyarakat Selain itu juga akan didapatkan jalinan kerjasama yang bagus antara masyarakat sebagai stakeholder UNPAM. Dengan berakhirnya acara pelatihan hand sanitizer otomatis dan santunan yatim duafa yang terdampak covid-19 di Mushola Al Ikhlas, maka seluruh rangkaian acara pengabdian kepada masyarakat ditutup.

\section{SIMPULAN}

Kegiatan PKM yang berbentuk dalam pelatihan pembuatan, pengunaan dan perawatan hand sanitizer ini berjalan lancar. Antusiasme peserta begitu besar, banyak pertanyaan dilontarkan peserta terkait masalah pnggunaan hand sanitizer otomatis. 
Begitu juga peran serta aktif anak yatim, dhuafa dan jamaah Musholla Al Ikhlas dalam praktikum yang langsung dibimbing mahasiswa beserta dosen. Berdasarkan hasil wawancara dan evaluasi, seluruh pengurus dan jamaah musholla Al Ikhlas merasakan manfaat materi protocol Covid-19. Pelaksanaan kegitan PKM dapat disimpulkan berhasil sampai tahap meningkatkan minat masyarakat dalam mempelajari teori-teori dasar dan ilmu-ilmu praktis yang terkait dengan pembuatan dan penggunaan hand sanitizer. Keberhasilan ini ditunjukkan antara lain : adanya komitmen bersama untuk menggunakan hand sanitizer secara benar, penerapan protocol kesehatan untuk memutus rantai Covid19, kemanfaatan santunan dan sembako dengan kebutuhan anak yatim dan dhuafa yang terdampak Covid-19. Masyarakat juga menyatakan ketertarikan kerjasama antara jamaah musholla untuk dijadikan binaan oleh prodi Teknik Elektro UNPAM dalam pengembangan kewirausahaan di beberapa sektor industry.

\section{DAFTAR PUSTAKA}

Hapsari, D.N. (2015). Pemanfaatan Ekstrak Daun Sirih (Piper Betle Linn) Sebagai Hand sanitizer. Skripsi. Poltekkes Kemenkes Yogyakarta

Iswanto, I. (2009). Belajar Mikrokontroler AT90S2313 Dengan Basic Compiler: Andi Publisher

Shrader, Robert L. (1991). Komunikasi Elektronika. Jakarta: Erlangga

Yuliana. (2020). Corona Virus Diseases (Covid-19): Sebuah Tinjauan Literatur. Wellness and Healthy Magazine. Volume 2 No. 1 Febuary 2020, p 187-192.

www.covid-19.go.id 